\title{
62. ORGANIC GEOCHEMISTRY OF SEDIMENTS CORED DURING DEEP SEA DRILLING PROJECT LEGS 56 AND 57, JAPAN TRENCH: ORGANIC PETROGRAPHY AND EXTRACTABLE HYDROCARBONS
}

\author{
J. Rullkötter, C. Cornford, ${ }^{1}$ P. Flekken, and D. H. Welte, Institute for Petroleum and Organic Geochemistry, \\ Kernforschungsanlage Jülich, Jülich, West Germany
}

\begin{abstract}
The quantity, type, and maturity of the organic matter of Quaternary and Tertiary sediments from the Japan Trench (DSDP Leg 56, Sites 434 and 436; and Leg 57, Sites 438, 439 and 440) were determined. The hydrocarbons in lipid extracts were analyzed by capillary-column gas chromatography and combined gas chromatography/mass spectrometry. Kerogen concentrates were investigated by microscopy, and vitrinite-reflectance values were determined.

Measured organic-carbon values were in the range of 0.13 to 1.00 per cent. Extract yields, however, were extremely low. Normalized to organic carbon, total extracts ranged from 4.1 to $15.7 \mathrm{mg} / \mathrm{g} \mathrm{C}_{\text {org. }}$. Gas chromatography of non-aromatic hydrocarbons showed that all sediments, except one Oligocene sample, contained very immature, mainly terrigenous organic material. This was indicated by $n$-alkane maxima at $\mathrm{C}_{29}$ and $\mathrm{C}_{31}$ and high odd-carbon-number predominances. Unsaturated steroid hydrocarbons were found to be major cyclic compounds in lower- and middle-Miocene samples from the upper inner trench slope (Sites 438 and 439). Perylene was the dominating aromatic hydrocarbon in all but the Oligocene sample.

Microscopy showed kerogens rich in terrigenous organic particles, with a major portion of recycled vitrinite. Nevertheless, almost all the liptinite particles appeared to be primary. This is a paradox, as the bulk of the samples were composed of hemipelagic mineral matter with a major siliceous biogenic (planktonic) component. A trend of reduced size and increased roundness can be seen for the vitrinite/inertinite particles from west to east (from upper inner trench slope to outer trench slope). All sediments but one are relatively immature, with mean huminite-reflectance values $\left(R_{O}\right)$ in the range of 0.30 to 0.45 per cent. The oldest and deepest sediment investigated, an Oligocene sandstone from Site 439 , yielded a mean vitrinitereflectance value of 0.74 per cent and a mature $n$-alkane distribution. This sample may indicate a geothermal event in late Oligocene time. It failed to affect the overlying lower Miocene and may have been caused by an intrusion. Boulders of acidic igneous rocks in the Oligocene can be interpreted as witnesses of nearby volcanic activity accompanied by intrusions.
\end{abstract}

\section{INTRODUCTION}

A transect of the Japan Trench east of Honshu Island was drilled on DSDP Legs 56 and 57. Drill-site locations (Figure 1) embraced the top of the trench inner wall (Sites 438 and 439, water depth $\sim 1600 \mathrm{~m}$ ), the upper slope (Site 435, water depth $3400 \mathrm{~m}$ ), a mid-slope terrace (Site 440 , water depth $4500 \mathrm{~m}$ ), the zone of accretion at the base of the slope (Site 434, water depth $5985 \mathrm{~m}$ ), and the outer-trench slope (Site 436, water depth $5240 \mathrm{~m}$ ). A major objective of this transect was the investigation of

\footnotetext{
'Present address: The British National Oil Corporation, Glasgow, Scotland.
}

the sedimentary organic matter in the active-margin zone of the Japan Trench. It was expected that analysis of drill cores would reveal any differences between the organic matter in the deep-sea sediments deposited on the Pacific plate, which is being subducted under the continental margin of Japan, and the organic matter of the continental-slope sediments. Another subject of special interest was the so-called "zone of accretion" at the foot of the slope, which was assumed to originate from sediments scraped off the oceanic crust during subduction. The Japan Trench had been considered an exception among the trenches of the circum-Pacific belt by being nearly devoid of terrigenous sediments (Scholl and Marlow, 1974). Investigation of the organic matter 


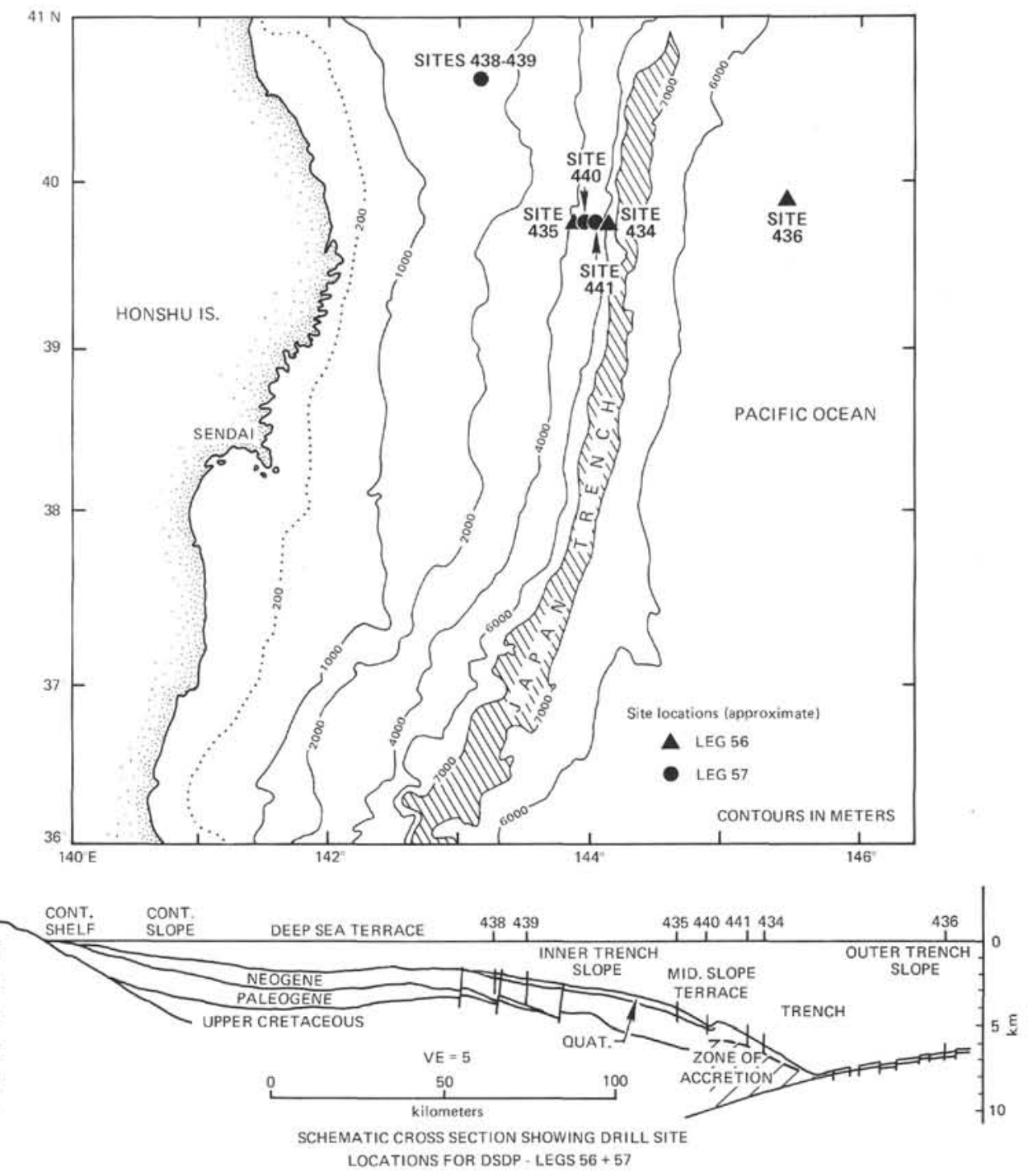

Figure 1. Location of sites drilled on the Japan Trench transect and schematic section showing drill sites. Section based on Ishiwada and Ogawa (1976) and Japan National Oil Corporation multi-channel data.

in the Legs 56 and 57 samples should indicate whether this statement is valid for the organic component of the sediments.

\section{SAMPLES}

Two core samples each from Sites 434 and 436, seven samples from Site 438, three samples from Site 439, and five samples from Site 440 were studied. Information on depth, stratigraphy, and lithology is given in Table 1.

\section{EXPERIMENTAL PROCEDURES}

Samples were received frozen. They were dried, ground, and extracted with dichloromethane, using a flow-through extraction cell (Radke et al., 1978). Total extracts were separated into non-aromatic hydrocarbons, aromatic hydrocarbons, and heterocompounds by medium-pressure micro-column liquid chromatography. Contents of total organic carbon were determined by combustion of $\mathrm{HCl}$-treated rock samples in an oxygen flow at $1300^{\circ} \mathrm{C}$ in a Leco carbon analyzer.

Capillary-column gas chromatography of hydrocarbon fractions was performed on a Siemens L 402 gas chromatograph equipped with a $25 \mathrm{~m} \times 0.3 \mathrm{~mm}$ i.d. glass capillary column coated with SE 54 . Hydrogen was used as carrier gas, and the oven temperature was programmed as follows: $80^{\circ} \mathrm{C}(2 \mathrm{~min}), 80$ to $250^{\circ} \mathrm{C}\left(3^{\circ} \mathrm{C} /\right.$ $\min ), 250^{\circ} \mathrm{C}(10 \mathrm{~min})$.

Mass spectrometric analyses were carried out using a Varian MAT 112 S mass spectrometer linked directly to a Varian 3700 gas chromatograph. Samples were injected splitless onto a $25 \mathrm{~m} \times 0.3 \mathrm{~mm}$ i.d. SE 54 glass capillary column. The oven was programmed from $100^{\circ} \mathrm{C}$ to $250^{\circ} \mathrm{C}$ at $4^{\circ} \mathrm{C} / \mathrm{min}$ (carrier gas: helium). The mass spectrometer was operated at $70 \mathrm{eV}$, and the source temperature was $220^{\circ} \mathrm{C}$. The magnet was scanned continuously at a rate of $1 \mathrm{~s} / \mathrm{dec}$. All data were stored and processed with a Kratos DS 50 S data system. 
TABLE 1

Description of Samples (depth, age, lithology, and present structural situation), Organic/Carbon Values, and External Data

\begin{tabular}{|c|c|c|c|c|c|c|c|c|c|c|}
\hline \multirow[b]{2}{*}{$\begin{array}{c}\text { Sample } \\
\text { (interval in } \mathrm{cm} \text { ) }\end{array}$} & \multirow[b]{2}{*}{$\begin{array}{l}\text { Sub-Bottom } \\
\text { Depth } \\
\text { (m) }\end{array}$} & \multirow[b]{2}{*}{ Age } & \multirow[b]{2}{*}{ Lithology } & \multirow[b]{2}{*}{$\begin{array}{l}\text { Present Structural } \\
\text { Position }\end{array}$} & \multirow[b]{2}{*}{$\begin{array}{l}\text { Corg } \\
(\%)\end{array}$} & \multicolumn{5}{|c|}{ Extract Yields } \\
\hline & & & & & & ppm & $\begin{array}{l}\mathrm{Mg} / \mathrm{g} \\
\mathrm{C}_{\mathrm{org}}\end{array}$ & $\begin{array}{c}\text { Non-Aromatic } \\
\text { HC } \\
(\%)\end{array}$ & $\begin{array}{l}\text { Aromatic } \\
\text { HC } \\
(\mathscr{\%})\end{array}$ & $\begin{array}{l}\text { Hetero- } \\
\text { Compounds } \\
(\%)\end{array}$ \\
\hline $\begin{array}{l}434-1-3,115-125 \\
434 \mathrm{~B}-15-1,107-117\end{array}$ & $\begin{array}{r}4.2 \\
419,1\end{array}$ & $\begin{array}{l}\text { Pleistocene } \\
\text { Lower Pliocene }\end{array}$ & $\begin{array}{l}\text { Diatomaceous ooze } \\
\text { Vitric-diatomaceous mudstone }\end{array}$ & $\begin{array}{l}\text { Zone of accretion (lower } \\
\text { inner trench slope) }\end{array}$ & $\begin{array}{l}0.87 \\
0.70\end{array}$ & $\begin{array}{r}136 \\
90\end{array}$ & $\begin{array}{l}15.7 \\
12.8\end{array}$ & $\begin{array}{l}8 \\
3\end{array}$ & $\begin{array}{l}10 \\
12\end{array}$ & $\begin{array}{l}82 \\
85\end{array}$ \\
\hline $\begin{array}{l}436-7-4,115-125 \\
436 \cdot 36 \cdot 2,115-125\end{array}$ & $\begin{array}{r}61.2 \\
333.7\end{array}$ & $\begin{array}{l}\text { Pleistocene } \\
\text { Middle/Late Miocene }\end{array}$ & $\begin{array}{l}\text { Diatomaceous muddy ooze } \\
\text { Radiolarian-diatomaceous } \\
\text { mudstone }\end{array}$ & Outer trench slope & $\begin{array}{l}0.26 \\
0.13\end{array}$ & $\begin{array}{r}48 \\
9\end{array}$ & $\begin{array}{r}18.5 \\
6.8\end{array}$ & $\begin{array}{l}25 \\
s 0^{b}\end{array}$ & $\begin{array}{l}21 \\
25^{b}\end{array}$ & $\begin{array}{l}54 \\
25 \mathrm{~b}\end{array}$ \\
\hline $438 \wedge-4-4,110-120$ & 47.7 & Pliocene/Pleistocene & Diatomaceous silty clay & & 0.41 & 41 & 10.1 & 27 & 27 & 46 \\
\hline $438-10-4,115-125$ & 84.7 & Upper Pliocene & Diatomaceous silty clay & & 0.60 & 58 & 9.7 & 26 & 20 & 54 \\
\hline $438 A-18-2,115-125$ & 223.2 & Lower Pliocene & Diatomaceous clay & & 0.90 & 124 & 13.8 & 8 & 11 & 81 \\
\hline $438 \mathrm{~A}-24-4,110-120$ & 283.2 & Lower Pliocene & Diat omaceous clay & Upper inner & 0.82 & 60 & 7.3 & 29 & 14 & 57 \\
\hline $438 \AA-46-3,110-120$ & 492.7 & Upper Miocene & $\begin{array}{l}\text { Mottled diatomaceous } \\
\text { claystone }\end{array}$ & trench slope & 0.61 & 64 & 10.4 & 22 & 19 & 59 \\
\hline $\begin{array}{l}438 \mathrm{~A}-70-4,110-120 \\
438 \mathrm{~A}-84-1,100-110\end{array}$ & $\begin{array}{l}722.2 \\
850.5\end{array}$ & Middle Miocene & Diatomaceous claystone & & 0.51 & 48 & 9.5 & 13 & 18 & $\begin{array}{l}69 \\
58\end{array}$ \\
\hline $438 \mathrm{~A}-84-1,100-110$ & 850.5 & Middle Miocene & Diatomaceous claystone & & 0.55 & 73 & 13.3 & 19 & 23 & 58 \\
\hline $\begin{array}{l}439-9 \cdot 4,100-110 \\
439-21 \cdot 2,115-125 \\
439-31-5,0-5\end{array}$ & $\begin{array}{r}893.2 \\
994.7 \\
\sim 1105\end{array}$ & $\begin{array}{l}\text { Lower Miocene } \\
\text { Lower Miocene } \\
\text { Upper Oligocene (?) }\end{array}$ & $\begin{array}{l}\text { Tuffaceous siltstone } \\
\text { Clayey siltstone } \\
\text { Sandstone }\end{array}$ & $\begin{array}{l}\text { Upper inner } \\
\text { trench slope }\end{array}$ & $\begin{array}{l}0.53 \\
0.33 \\
0.33\end{array}$ & $\begin{array}{l}59 \\
20 \\
46\end{array}$ & $\begin{array}{r}11.1 \\
8.5 \\
14.0\end{array}$ & $\begin{array}{r}31 \\
9 \\
49\end{array}$ & $\begin{array}{l}14 \\
14 \\
29\end{array}$ & $\begin{array}{l}55 \\
77 \\
22\end{array}$ \\
\hline $\begin{array}{l}440 \mathrm{~B}-3-5,110-120 \\
440 \mathrm{~B}-17-5,125-135\end{array}$ & $\begin{array}{l}165.6 \\
298.7\end{array}$ & $\begin{array}{l}\text { Pleistocene } \\
\text { Pleistocene }\end{array}$ & $\begin{array}{l}\text { Diatomaceous clay } \\
\text { Claystone }\end{array}$ & & $\begin{array}{l}0.98 \\
0.59\end{array}$ & $\begin{array}{r}112 \\
43\end{array}$ & $\begin{array}{r}11.4 \\
7.2\end{array}$ & $\begin{array}{l}12 \\
18\end{array}$ & $\begin{array}{l}16 \\
18\end{array}$ & $\begin{array}{l}72 \\
64\end{array}$ \\
\hline $4408-39-3,115-125$ & 504.7 & Lower Pliocene & Diatomaceous claystone & Mid-slope terrace & 0.60 & 75 & 12.5 & 11 & 23 & 66 \\
\hline $440 \mathrm{~B}-51-3,125-135$ & 618.7 & Lower Pliocene & Claystone & & 0.37 & 45 & 12.1 & 15 & 30 & 55 \\
\hline $440 \mathrm{~B}-68-2,110-120$ & 778.6 & Upper Miocene & Silty chystone & & 1.00 & 41 & 4.1 & 16 & 19 & 65 \\
\hline
\end{tabular}

acialculated.

bVylues questionable because of extremely low weight of fractions.

Details of the experimental procedures for microscopic investigations have been described in a previous paper (Cornford et al., 1979). In brief, the extracted sediments were treated with $\mathrm{HCl}$, and a kerogen concentrate was floated off, using a solution of $1.9 \mathrm{~g} / \mathrm{cm}^{3}$ density. The kerogen concentrate was trapped on a filter and dried, and a smear slide was prepared for observation in transmitted light. Where sufficient material was obtained, the kerogen was embedded in "Araldite" and polished for observation in reflected light. Reflectance was measured with a Zeiss MPM 01 photometer interfaced with a Digital Equipment PDP 11/10 computer, using non-polarized light and oil immersion. The huminite/vitrinite reflectance, where quoted, is the arithmetic mean of the values in the lowest histogram peak. Each reflectance value is fed into the computer with a maceral identifier $(\mathrm{L}=$ Liptinite, $\mathrm{V}=$ vitrinite/huminite, $\mathrm{I}=$ inertinite, $\mathrm{X}=$ unknown). Histograms are then generated both for the reflectance values and for the maceral distribution, using 0.05 per cent intervals.

\section{RESULTS}

\section{Organic-Carbon Values and Extractable Organic Matter}

The organic carbon content (Table 1) was found to vary in the range of 0.13 to 1.00 per cent: the lowest value comes from the oxidized pelagic Miocene of Section 436-36-2, while the majority of values are above 0.5 per cent $\mathrm{C}_{\text {org }}$. In contrast to the fairly high values of total organic carbon of the sediments, the yields of extractable organic matter are low (Table 1). Normalized to organic carbon, extract yields between 4.1 and 18.5 $\mathrm{mg} / \mathrm{g} \mathrm{C}_{\text {org }}$ were obtained. Compared, for example, with the results reported for Leg $47 \mathrm{~A}$ samples from the continental rise of the eastern North Atlantic (Cornford et al., in press), the Leg 56/57 values are lower by a factor of five to ten.

Liquid chromatographic separation of the total extracts yielded varying amounts of hydrocarbons (Table
1); typical values are between 25 and 45 per cent total hydrocarbons. No clear depth or age trend can be established. All values, however, have to be interpreted with great care, because of the very low absolute weight of the chromatographic fractions.

\section{Non-Aromatic Hydrocarbons}

The capillary-column gas chromatograms of the nonaromatic hydrocarbon fractions show similar $n$-alkane distributions for all samples, with the exception of the oldest (Oligocene) section from Site 439 (439-31-5), which will be described separately. From the normalized $n$-alkane distributions (Figures 2-4), maxima at $n-\mathrm{C}_{29}$ or $n-\mathrm{C}_{31}$ are evident. The high odd-carbon-number predominance in the range of $n-\mathrm{C}_{25}$ to $n-\mathrm{C}_{31}$ indicates low maturities for all samples. Below $n-\mathrm{C}_{23}$ there is a more uniform $n$-alkane distribution without any pronounced predominance (Table 2 ).

Pristane and phytane are minor components in most of the samples. Where calculation of a pristane/phytane ratio was possible (Table 2 ), this ratio turns out to be below 1 except for two Pleistocene sections (440B-3-5 and 440B-17-5) and an upper-Miocene section (440B-682) from Site 440 .

The general pattern of non-aromatic hydrocarbon distributions is represented by Section 440B-3-5 in Figure 5 (top). The $n$-alkanes are dominant, and the high-molecular-weight cyclic hydrocarbons mainly consist of saturated triterpanes, probably of the hopane series, although unambiguous identifications were not possible, because of the low extract yields.

A significantly higher concentration of $\mathrm{C}_{27}$ cyclic hydrocarbons - relative to all other sediments investigated - was observed in three lower- and middleMiocene sections from Sites 438 and 439 (438A-70-4, 438A-84-1, and 439-9-4). Figure 5 (bottom) shows the capillar-column gas chromatogram of the non-aromatic hydrocarbon fraction of Section 438A-84-1. Compounds tentatively identified by interpretation of their mass spectra and by comparison with previous results from 
J. RULLKÖTTER, C. CORNFORD, P. FLEKKEN, D. H. WELTE

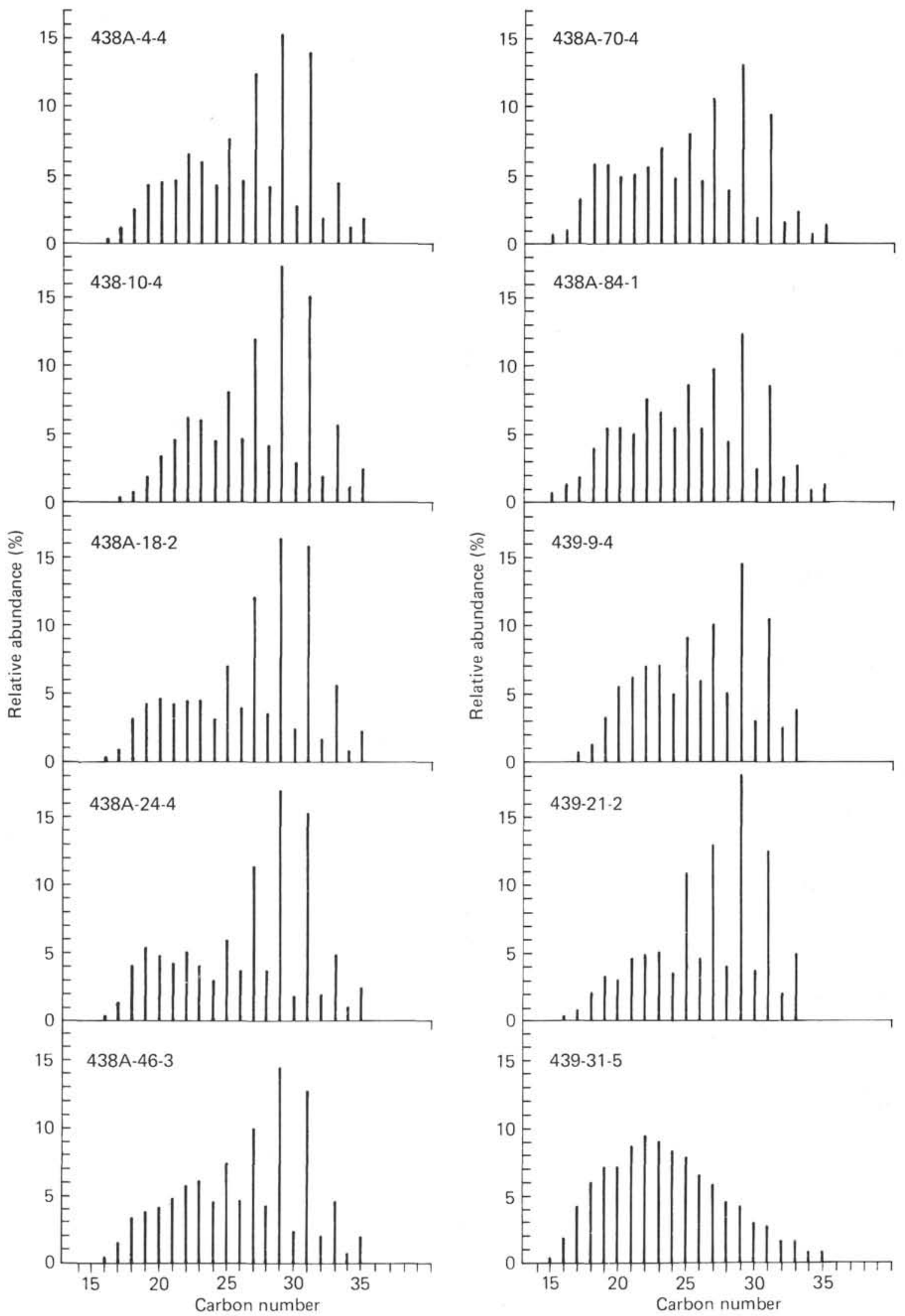

Figure 2. Normalized $\mathrm{n}$-alkane distributions for samples from DSDP Sites 438 and 439, upper inner trench slope. 


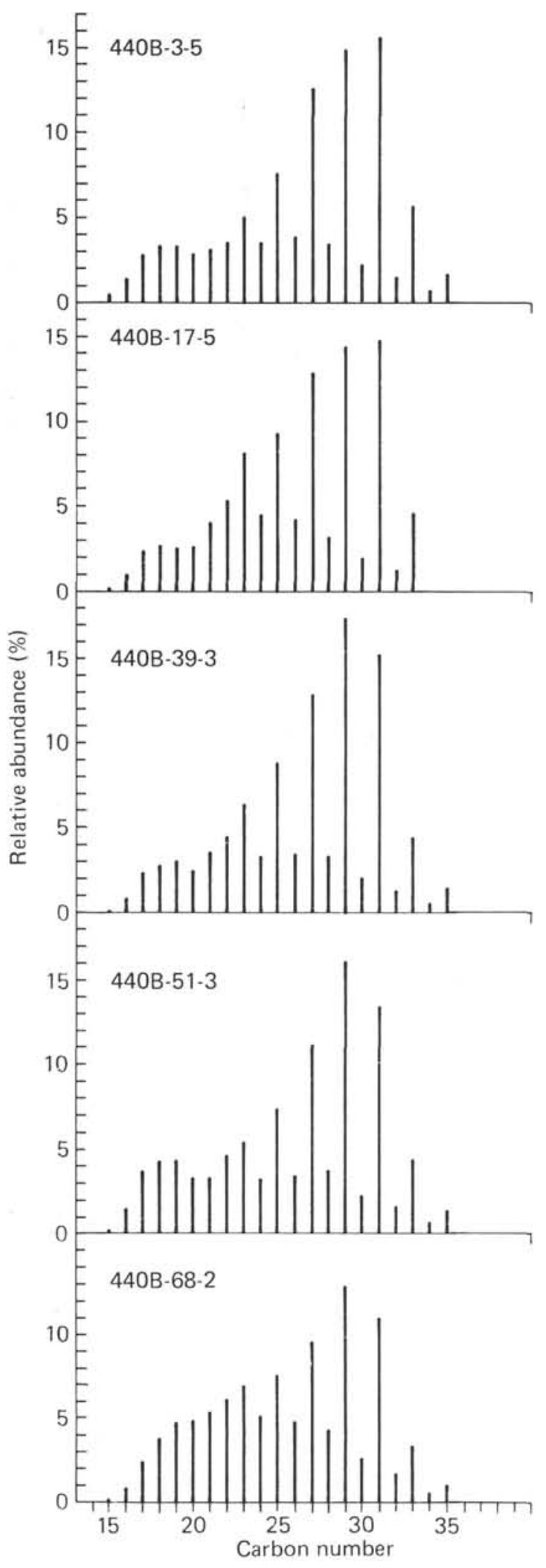

Figure 3. Normalized $\mathrm{n}$-alkane distributions for samples from DSDP Site 440, mid-slope terrace.
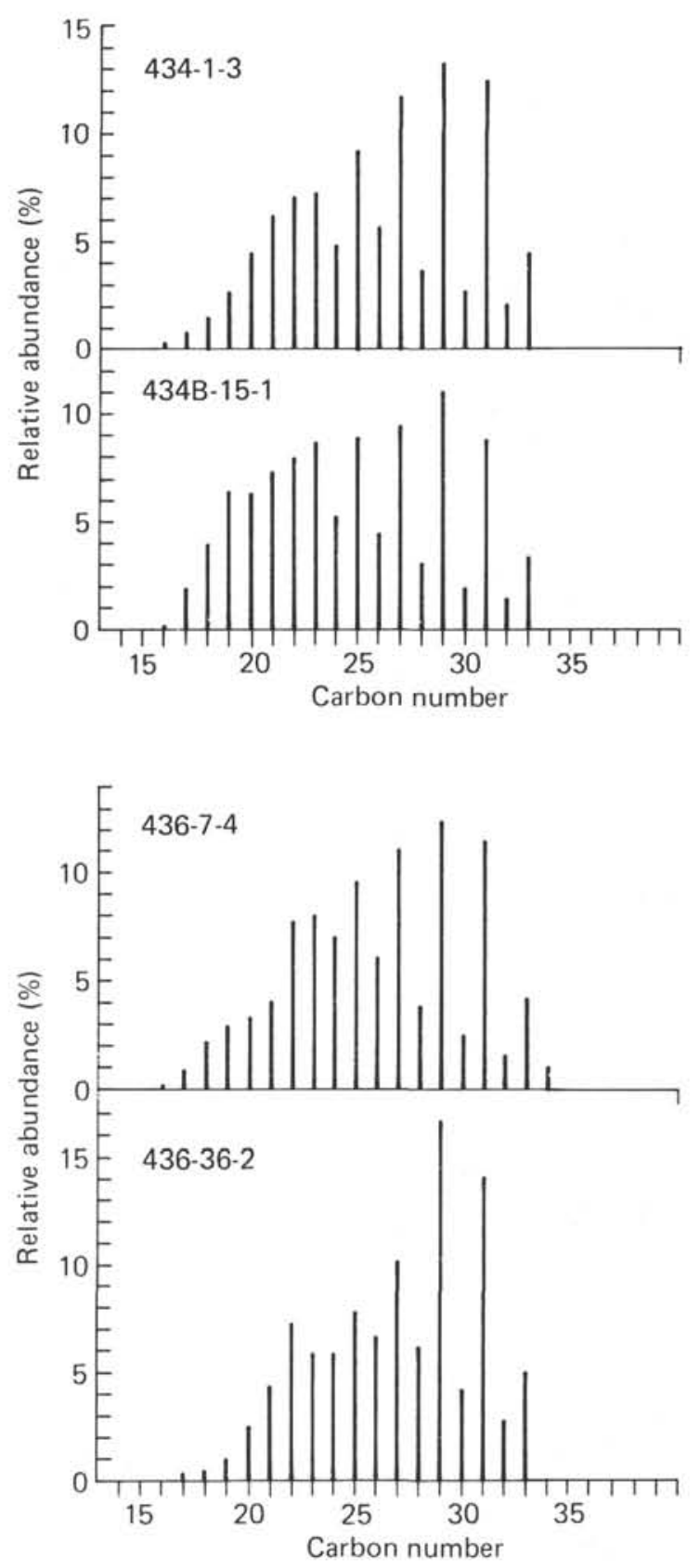

Figure 4. Normalized $\mathrm{n}$-alkane distributions for samples from DSDP Site 434, lower inner trench slope (zone of accretion), and DSDP Site 436, outer trench slope.

DSDP Leg 47A (Cornford et al., 1979) and Leg 50 (Rullkötter, unpublished) are listed in Table 3. Besides two $\mathrm{C}_{30}$ pentacyclic triterpenes, a variety of homologous unsaturated steroid hydrocarbons in the range of $\mathrm{C}_{27}$ to $\mathrm{C}_{29}$ were detected. Two double-bond isomers were present in each case. Sterenes were found to be $\Delta^{4}$ - and $\Delta^{5}$-isomers, steradienes could be identified as $\Delta^{4,22}$ and $\Delta^{5,22}$-compounds, respectively (Figure 6). Cyclic compounds not 
TABLE 2

Carbon Preference Indexes (CPI) and Pristane/Phytane Ratios for Non-aromatic Hydrocarbon Fractions

\begin{tabular}{|c|c|c|c|c|}
\hline $\begin{array}{c}\text { Sample } \\
\text { (interval in } \mathrm{cm} \text { ) }\end{array}$ & $\mathrm{CPI}_{19-23}$ & $\mathrm{CPI}_{25-31}$ & $\mathrm{CPI}_{29}$ & $\begin{array}{l}\text { Pristane/ } \\
\text { Phytane }\end{array}$ \\
\hline $\begin{array}{l}434-1-3,115-125 \\
434 \mathrm{~B}-15-1,107-117\end{array}$ & $\begin{array}{l}1.11 \\
1.19\end{array}$ & $\begin{array}{l}3.08 \\
3.09\end{array}$ & $\begin{array}{l}4.30 \\
4.46\end{array}$ & $\begin{array}{l}0.60^{\mathrm{a}} \\
0.40\end{array}$ \\
\hline $\begin{array}{l}436-7-4,115-125 \\
436-36-2,115-125\end{array}$ & $\begin{array}{l}0.98 \\
0.92\end{array}$ & $\begin{array}{l}2.79 \\
2.32\end{array}$ & $\begin{array}{l}4.00 \\
3.24\end{array}$ & $0.77^{\mathrm{a}}$ \\
\hline $\begin{array}{l}438 \mathrm{~A}-4-4,110-120 \\
438-10-4,115-125 \\
438 \mathrm{~A}-18-2,115-125 \\
438 \mathrm{~A}-24-4,110-120 \\
438 \mathrm{~A}-46-3,110-120 \\
438 \mathrm{~A}-70-4,110-120 \\
438 \mathrm{~A}-84-1,100-110\end{array}$ & $\begin{array}{l}1.03 \\
1.05 \\
1.07 \\
1.01 \\
1.07 \\
1.14 \\
0.98\end{array}$ & $\begin{array}{l}3.61 \\
3.58 \\
4.27 \\
4.31 \\
3.09 \\
3.06 \\
2.55\end{array}$ & $\begin{array}{l}4.73 \\
5.02 \\
5.62 \\
6.26 \\
4.34 \\
4.36 \\
3.61\end{array}$ & $\begin{array}{l}0.67 \\
0.25^{\mathrm{a}} \\
0.62 \\
0.62 \\
0.69 \\
0.91 \\
0.38\end{array}$ \\
\hline $\begin{array}{l}439-9-4,100-110 \\
439-21-2,115-125 \\
439-31-5,0-5\end{array}$ & $\begin{array}{l}1.07 \\
1.20 \\
1.04\end{array}$ & $\begin{array}{l}2.51 \\
3.59 \\
1.12\end{array}$ & $\begin{array}{l}3.63 \\
4.63 \\
1.11\end{array}$ & $\begin{array}{l}0.99^{\mathrm{a}} \\
0.38^{\mathrm{a}} \\
1.9\end{array}$ \\
\hline $\begin{array}{l}440 B-3-5,110-120 \\
440 B-17-5,125-135 \\
440 B-39-3,115-125 \\
440 B-51-3,125-135 \\
440 B-68-2,110-120\end{array}$ & $\begin{array}{l}1.17 \\
1.28 \\
1.30 \\
1.12 \\
1.11\end{array}$ & $\begin{array}{l}4.15 \\
4.34 \\
4.95 \\
4.07 \\
2.72\end{array}$ & $\begin{array}{l}5.16 \\
5.72 \\
6.44 \\
5.40 \\
3.65\end{array}$ & $\begin{array}{l}1.1 \\
1.4 \\
0.77 \\
0.91 \\
1.3\end{array}$ \\
\hline
\end{tabular}

aVery low pristane and phytane concentrations.

marked in Figure 5 (bottom) are saturated triterpanes of the hopane/moretane series $\left(\mathrm{C}_{27}\right.$ to $\left.\mathrm{C}_{31}\right)$.

Section 439-31-5, probably upper Oligocene, shows a completely different $n$-alkane distribution, with a maximum at $n-\mathrm{C}_{22}$ (Figure 2) and a carbon-preference index near unity (Table 2), a distribution very similar to that of a mature crude oil. The pristane/phytane ratio of 1.9 is the highest value observed in the Leg 56/57 series of samples. Although the possibility of indigenous maturation or of migrated hydrocarbons present in this Oligocene sandstone sample will be discussed in the next section, contamination cannot be fully excluded.

\section{Aromatic Hydrocarbons}

Perylene was detected as the most abundant aromatic hydrocarbon in all immature sediment samples. The Oligocene Section (439-31-5) showed a distribution of aromatic hydrocarbons typical for higher-maturity sediments.

\section{Microscopy}

The microscopy of all samples revealed kerogens dominated by terrestrial-higher-plant debris. A brief description of each sample is given in Table 4, the liptinite content being estimated from transmitted-light preparations, while the distinction between huminite/ vitrinite and inertinite was made using polished blocks (Stach et al., 1975).

The majority of observed particles were huminite/ vitrinite and inertinite. The reflected-light preparations also revealed a significant portion of cell-wall debris, consisting of amber-colored, relatively thin humotelinitic wall fragments. In Pliocene diatom oozes (438A$18-2$ and $438 \mathrm{~A}-24-4)$ they were obviously derived from xylem cells with bordered pits, probably indicating coni- fers as the source. Pollen was common throughout, with the exception of Sections 439-21-2 and 439-31-5: the former contained a dominance of larger humic (lignite?) particles, while the latter, a silty sandstone, contained almost exclusively finer-grained vitrinite and inertinite. Also of significance was a large $(60-80 \mu \mathrm{m})$, subcircular, thin-walled pollen or algal body which appeared only in the Plio-Pleistocene, but at all investigated sites.

Reflected-light preparations showed the kerogen from the Miocene claystone of 439-21-2 to contain many lignite-type fragments which were multimacerites (particles containing two or three maceral groups). In this case, huminite was mixed with sporinite (mega- and microspores). Multimacerites had slightly higher reflectance levels $(0.43-0.49 \%)$ than monomacerites $(0.41-$ $0.44 \%$ ), although such a small difference should not be taken as significant. Sclerotinite particles (fungal spore bodies) in bimacerites showed reflectance levels of 0.48 and 0.43 per cent. Sclerotinites were also seen in the Pliocene diatom mudstone of 434B-15-1, the Pliocene diatom ooze of 438A-24-4, the Pliocene diatom clay of 438B-3-5, and the Pleistocene diatom ooze of 440B$39-3$, with reflectance values of $0.37,0.49,0.56$, and 0.39 per cent, respectively.

Two types of reflectance data were recorded, random reflectance histograms of all measurable particles (Figures 7-9) and selected measurements on the lowest reflectance huminite/vitrinite particles found (Figure 10 and Table 5). Reflectance histograms of all measurable particles were generated in two ways (Figures 7a and $7 \mathrm{~b}$ ), showing both the maceral distribution and the actual reflectance values. Figure 7, representing a Pliocene diatom mudstone (434B-15-1), is generally typical of all samples, except the lignite-type materials of 439-21-2. It contains multimodal huminite/vitrinite peaks, little liptinite, and a significant amount of inertinite. These histograms are biased, since often small liptinite or inertinite particles (e.g., $<5 \mu \mathrm{m}$ ) could not be measured.

Figure 8 contrasts the maceral distributions in diatom oozes from the upper inner trench slope (438-10-4) and the outer trench slope (436-7-4), the two samples being of Pliocene and Pleistocene age, respectively. Figure 9 shows the maceral distributions in the deepest sample analyzed, the Oligocene silty sandstone of 431-39-5, and the Pliocene diatom claystone of 440B-39-3 from the mid-slope terrace. Types of reflectance distribution, where measured, are noted in Table 5.

Table 5 also contains the huminite/vitrinite-reflectance data that come from selected particles of the lowest-reflectance huminite/vitrinite. The mean reflectance values place limits on the maturity of the samples, but for reasons given in the next section these data are not very reliable.

\section{SUMMARY AND INTERPRETATION}

On the basis of the low extract yields and the high odd-carbon-number predominance of the $\mathrm{C}_{25}$ to $\mathrm{C}_{33}$ $n$-alkanes in the extractable lipid hydrocarbon fractions, the organic matter of all sediments drilled during the DSDP Legs 56 and 57 transect of the Japan Trench - 

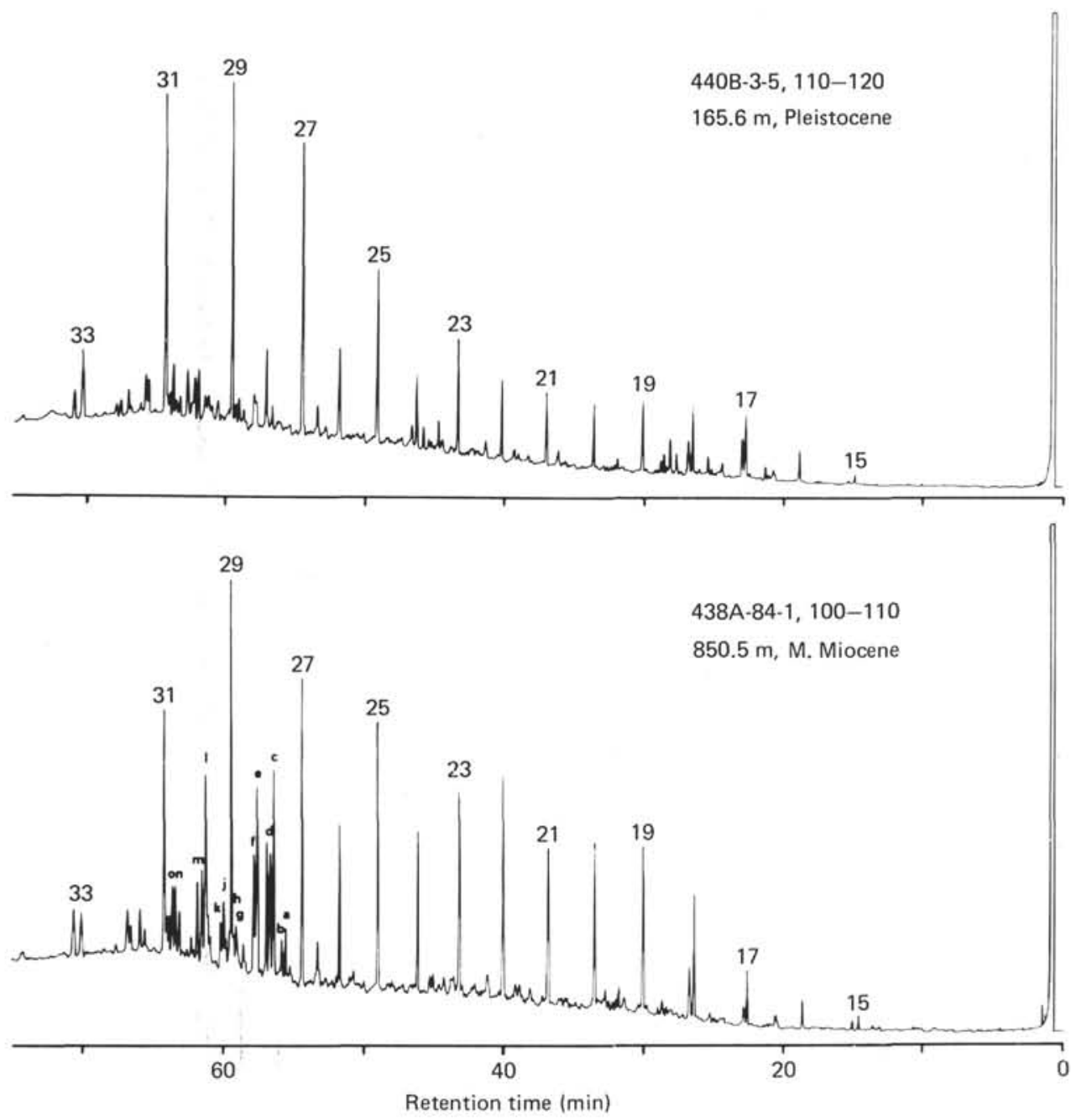

Figure 5. Capillary-column gas chromatograms of Sample 440B-3-5, 110-120 cm representing the general pattern of non-aromatic hydrocarbon distributions in DSDP Legs 56 and 57 sediments, and of Sample 438A-84-1, 100-110 cm containing large amounts of unsaturated polycyclic hydrocarbons. Numbers indicate $\mathrm{n}$-alkanes, letters mark compounds tentatively identified by mass spectrometry (see Table 3).

except the Oligocene sandstone of 439-31-5 - can be described as immature and predominantly terrigenous. This is true for the sequences of the continental-slope sediments as well as for the sediments deposited on the crust of the Pacific plate, at least after the middle Miocene. This is also confirmed by the microscopic investigations. Huminite-reflectance values (Table 5; Figure 10) are all below 0.52 per cent with the exception of the silty sandstone of 439-31-5 at about $1105 \mathrm{~m}$ depth, which had a mean vitrinite reflectance of 0.74 per cent.

However, because the total-reflectance histograms (Figures 7-9; Table 5) show such an abundance of higher-reflectance particles, there is no certainty that any of the measured huminite/vitrinite is primary and affected only by diagenesis/catagenesis during its last depositional cycle. Indeed, with the exception of the lowest two samples at Site 439, the transmitted-light preparations all show highly immature yellow pollen, spores, and cuticles; only in Section 440B-68-2 were reworked (orange and granular) spores apparent.

As was discussed in studies of Cretaceous argillaceous sediments from DSDP Site 398 (Cornford, 1979) the higher-reflectance huminite/vitrinite has been attributed to eroded coals or associated organic-matter-rich sediments in the source area. Distal transport through oxidizing waters could also increase the reflectance of the particles. This explanation seems more reasonable for the broad reflectance "humps" (e.g., Figure 9b) seen in a number of samples (Table 5) than for the multimodal distributions shown in Figures 7, 8a, or 9a. In addition, such oxidation should produce some brighter-reflecting oxidation rims with darker cores in the particles: no such rims were observed. In favor of a recycled-coal or -kerogen 
TABLE 3

Unsaturated Polycyclic Hydrocarbons in the Non-aromatic Hydrocarbon Fraction of Sample 438A-84-1, 100-110 $\mathrm{cm}^{\mathrm{a}}$

\begin{tabular}{clc}
\hline GC Peak & \multicolumn{1}{c}{ Compound } & Molecular Ion $\left(\mathrm{M}^{+}\right)$ \\
\hline a & Cholest-4,22-diene (?) & 368 \\
b & Cholest-5,22-diene (?) & 368 \\
c & Cholest-4-ene & 370 \\
d & Cholest-5-ene & 370 \\
e & Ergosta-4,22-diene & 382 \\
f & Ergosta-5,22-diene & 382 \\
g & Ergost-4-ene (?) & 384 \\
h & Ergost-5-ene (?) & 384 \\
j & Sitosta-4,22-diene (?) & 396 \\
k & Sitosta-5,22-diene (?) & 396 \\
1 & Sitost-4-ene & 398 \\
m & Sitost-5-ene & 398 \\
n & C 30 pentacyclic triterpene & 410 \\
o & C 30 pentacyclic triterpene & 410 \\
\hline
\end{tabular}

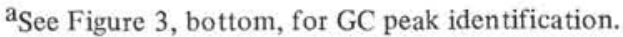
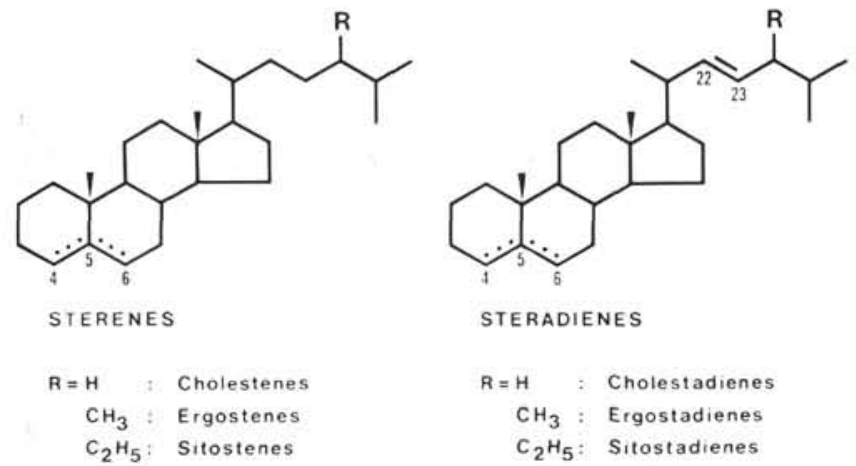

Figure 6. Molecular structures of unsaturated steroid hydrocarbons tentatively identified in Section 438A-3-5.

origin is the presence of discrete peaks of higher-rank matter, multimacerites in Section 439-21-2, and anomalously dark and granular spores in Section 440B-68-2. Spores generally lighten in color with oxidation (Stach et al., 1975). Further evidence of recycled matter is the poor correlation of the values of the lowest-huminite/vitrinite-reflectance population with depth (Figure 10). This suggests that the particles reached their present maturity levels before incorporation into the sediments.

The recycled-organic-matter origin requires a massive and long-term input of particles from the Oligocene to the Pleistocene, on both sides of the trench (Figures 7a and $7 \mathrm{~b}$ ). This homogeneity is surprising, but coals of appropriate maturities (brown coals to medium-volatile bituminous coals) are currently being eroded on the Japanese Islands (Matveef, 1972).

The huminite-reflectance trend, tentatively sketched on Figure 10, is at variance with the logged down-holetemperature data, which indicate gradients of about $30^{\circ} \mathrm{C} / \mathrm{km}$ at Site 438 and $10^{\circ} \mathrm{C} / \mathrm{km}$ at Site 440 . No significant difference is observed in the organic-matter maturity trends of the two sites. This anomaly can be explained if most of the reflectance measurements of Figure 10 were made on recycled particles, the trend with depth then being largely fortuitous. This seems also to be indicated by consideration of the time/temperature relationship to huminite reflectance. Section 439$21-2$, at $994 \mathrm{~m}$ depth, has a reliable reflectance level of 0.45 per cent. If the geothermal gradient at Sites 438 and 439 is taken at $30^{\circ} \mathrm{C} / \mathrm{km}$, this corresponds to about $36^{\circ} \mathrm{C}$ (estimate of $6^{\circ} \mathrm{C}$ at sea floor). The significant burial at Sites 438 and 439 is Plio-Pleistocene. A temperature of $36^{\circ} \mathrm{C}$, however, is too low to give 0.45 per cent with Plio-Pleistocene burial (Dow, 1978). This indicates that the particles arrived at the sites with an elevated reflectance level.

Estimates of the size of the huminite-vitrinite/inertinite particles seen in reflected light (Table 4) show a trend of coarser and more-angular grains in the innerslope samples from Sites 438 and 439 , while the moredistal, outer-slope Site 436 and the lower-inner-slope Site 434 show finer and more-rounded grains. The midslope terrace Site 440 , with more-rounded and finergrained particles, shows more similarities with the distal sites (Table 4). This clear correlation of huminite-vitrinite/inertinite particle size and shape with transport distance must stem from the fact that most of the material is recycled and started its final depositional cycle in the form of partially consolidated peats or coals. It has thus been fractionated mainly on the basis of size, since density and shape will have been relatively constant. A further trend, one of reduction in diversity of the liptinites away from the continent, appears to occur, but the small number of samples and the qualitative nature of the analysis means that confirmatory data should be sought. Both these trends - reduction in size and angularity, and the impoverishment of the mainly higherplant-derived liptinite populations - indicate a derivation of the organic components from the west, the midslope terrace trapping the material destined for the outer trench slope.

The multimacerite particles of the Miocene claystone Section 439-21-2 may well be attributable to a source on the postulated nearby Oyashio landmass (Figure 11). The existence of the Oyashio landmass near Sites 438 and 439 also explains the higher abundance of unsaturated cyclic hydrocarbons in lower- to middle-Miocene sediments drilled at these sites (Figure 5, bottom; Table $3)$. Preservation of large amounts of chemically rather unstable compounds like sterenes and steradienes in deep-sea sediments has been observed during investigation of core samples from DSDP Leg 47A (Cornford et al., in press) and Leg 50 (Rullkötter, unpublished). In all cases, these compounds were found in slumped and turbiditic sediment sequences originating from downslope mass flows at a continental margin. It can be assumed that the organic matter in these sediments originally was produced in an oxygen-minimum layer with high bioproductivity at the shelf edge (Welte et al., 1979). Early down-slope transport after primary sedimentation can account for the preservation of unsaturated steroid hydrocarbons, because early diagenetic 
TABLE 4

Kerogen Compositional Data

\begin{tabular}{|c|c|c|c|c|}
\hline $\begin{array}{l}\text { Sample } \\
\text { (interval in } \mathrm{cm} \text { ) }\end{array}$ & Macerals $^{\mathrm{a}}$ & $\begin{array}{l}\text { Sizeb } \\
(\mu \mathrm{m})\end{array}$ & $\begin{array}{l}\text { Preser- } \\
\text { vation }\end{array}$ & Features Apparent in Transmitted Light \\
\hline $434-1-3,115-125$ & $30: 40: 30$ & $10-20$ & M & Pollen, cuticle, woody cell debris. \\
\hline $434 \mathrm{~B}-15-1,107-117$ & $70: 10: 20$ & 15 & $\mathrm{~F}$ & $\begin{array}{l}\text { Much fine-grained vitrinite and inertinite; pollen and } \\
\text { woody debris. }\end{array}$ \\
\hline $436-7-4,115-125$ & $65: 20: 15$ & 10 & $\mathrm{~F}$ & As above. \\
\hline $436-36-2,115-125$ & $48: 50: 2$ & 15 & M & Poor recovery; rounded, well-sorted inertinite. \\
\hline $438 \mathrm{~A}-4-4,110-120$ & $30: 40: 30$ & 80 & G & Inertinite subangular; a few reworked spores. \\
\hline $438-10-4,115-125$ & $45: 25: 30$ & 30 & $\mathrm{~F}$ & Subangular to rounded inertinite; degraded liptinite. \\
\hline $438 \mathrm{~A}-18-2,115-125$ & $30: 30: 40$ & 250 & G & Inertinite subangular to angular; pollen, cuticle. \\
\hline $438 \mathrm{~A}-24-4,110-120$ & $50: 40: 10$ & 50 & $\mathrm{~F}$ & lnertinite rounded to subangular; cuticle, pollen. \\
\hline $438 \mathrm{~A}-46-3,110-120$ & $60: 20: 20$ & 30 & $\mathrm{~F}$ & Inertinite rounded and subrounded; degraded liptinite. \\
\hline $438 \mathrm{~A}-70-4,110-120$ & $40: 30: 20$ & 20 & $\mathrm{~F}$ & Few larger vitrinite and inertinite fragments. \\
\hline $438 \mathrm{~A}-84-1,100-110$ & $60: 20: 20$ & 30 & M & Fine-grained, subangular inertinite. \\
\hline $439-9-4,100-110$ & $50: 20: 30$ & 20 & M & As above; pollen. \\
\hline $439-21-2,115-125$ & $95: 5: 1$ & 500 & - & Lignite (?) fragments; multimacerites. \\
\hline $439-31-5,0-5$ & $85: 15: 1$ & - & M & As above, but much finer grained. \\
\hline $440 \mathrm{~B}-3-5,110-120$ & $65: 15: 20$ & 30 & $\mathrm{~F}$ & Cuticle, pollen, xylem tracheids with bordered pits. \\
\hline $440 \mathrm{~B}-17-5,125-135$ & $45: 50: 5$ & 15 & $\mathrm{M}$ & Inertinite rounded to subangular; fine liptinite debris. \\
\hline $440 \mathrm{~B}-39-3,115-125$ & $50: 30: 20$ & 10 & $\mathrm{~F}$ & Much fine, rounded inertinite. \\
\hline $440 \mathrm{~B}-51-3,125-135$ & $55: 30: 15$ & 15 & $\mathrm{~F}$ & Rounded inertinite, flaky liptinite. \\
\hline $440 \mathrm{~B}-68-2,110-120$ & $55: 35: 10$ & 20 & $\mathrm{~F}$ & As above; some reworked spores. \\
\hline
\end{tabular}

aHuminite/vitrinite: inertinite: liptinite

${ }^{b}$ Size of vitrinite/inertinite particles in transmitted light.

cPoor, moderate, fair, good.

transformation of sterols assisted by micro-organisms starts in the uppermost sediment layers (e.g., Nishimura, 1978). Rapid burial of the slumped and turbiditic sediments may have protected their organic matter against further attack by oxygen-enriched deep waters and micro-organisms. The $n$-alkane distributions of these sediments from Sites 438 and 439 (Figures 2 and 5 , bottom) show, however, that they contain considerable amounts of terrigenous organic matter. Together with the organic-carbon content of only about 0.5 per cent, this means that even in these sediments, which show better preservation of organic matter than any other sediments drilled during Legs 56 and 57, the potential for petroleum-hydrocarbon generation has to be rated low.

Typical non-aromatic-hydrocarbon distributions of Legs 56 and 57 sediments (Figure 5, top) show a dominance of terrigenous wax alkanes. Distal transport from the Japanese landmass prior to final deposition - perhaps comprising periods of non-reducing environments - favors preservation of fully saturated alkanes without functional groups. Terrigenous organic material generally seems to be more resistant to degradation than marine organic matter (cf. Cornford et al., in press). This might explain the terrigenous character of the soluble organic matter even in the oxidized pelagic Miocene sediment of $436-36-2$, recovered at Site 436 on the outer trench wall. This gives rise to difficulties in differentiation between the organic matter of the deep-sea sediments and the organic matter in the continental-slope deposits, especially in consideration of the origin of the sedimentary organic matter of the accretionary wedge.

The Oligocene silty sandstone of 439-31-5 shows hydrocarbon distributions that are typical for mature organic matter. Although contamination should not be fully excluded, an explanation for this observation might be given by boulders of acidic igneous rocks discovered in Cores 439-32 to 439-36, which point to nearby volcanic activity. Thus, it is not completely unlikely that locally high heat flow produced high-maturity organic matter, which led to migration of hydrocarbons into the sandstone. However, since microscopy shows Section 439-31-5 to contain vitrinite with anomalously high reflectance (Table 5 ; Figure 9a), the sediment itself may either be of higher maturity or contain allochthonous, recycled particles of higher rank. In any case, the good agreement between extractable-hydrocarbon analysis and kerogen microscopy seems to rule out contamination. Recycled particles normally do not contain much extractable organic matter, while this sample has a high extract yield $\left(14 \mathrm{mg} / \mathrm{g} \mathrm{C}_{\text {org }}\right.$ ) compared to most others (Table 1). In the absence of an Oligocene/Miocene unconformity, the evidence thus seems to point to a late-Oligocene source of geothermal heat which produced a vitrinite-reflectance level of 0.74 per cent in Section 439-31-5, but the heat source had cooled by the early Miocene, leaving Section 439-21-2, some $110 \mathrm{~m}$ higher, with a reliable huminite-reflectance level of not more than 0.45 per cent.

\section{ACKNOWLEDGMENTS}

We would like to thank Dr. M. Radke and Dr. R. G. Schaefer for carrying out extraction and gas chromatography, respectively, and Miss I. Jacobs, Miss M. Neumann, Mr. W. Benders, Mr. U. Disko, Mr. F. J. Keller, Mr. K. Otterberg, Mr. J. Schnitzler, Mr. H. G. Sittardt, and Mr. H. Willsch for technical assistance. Our thanks go to Dr. M. Bjorøy (Continental Shelf Institute, Trondheim, Norway), Dr.-Ing. H. W. 
E.D.G. NUMBER: K4617C.JOA TIATE: 24-AUG-78
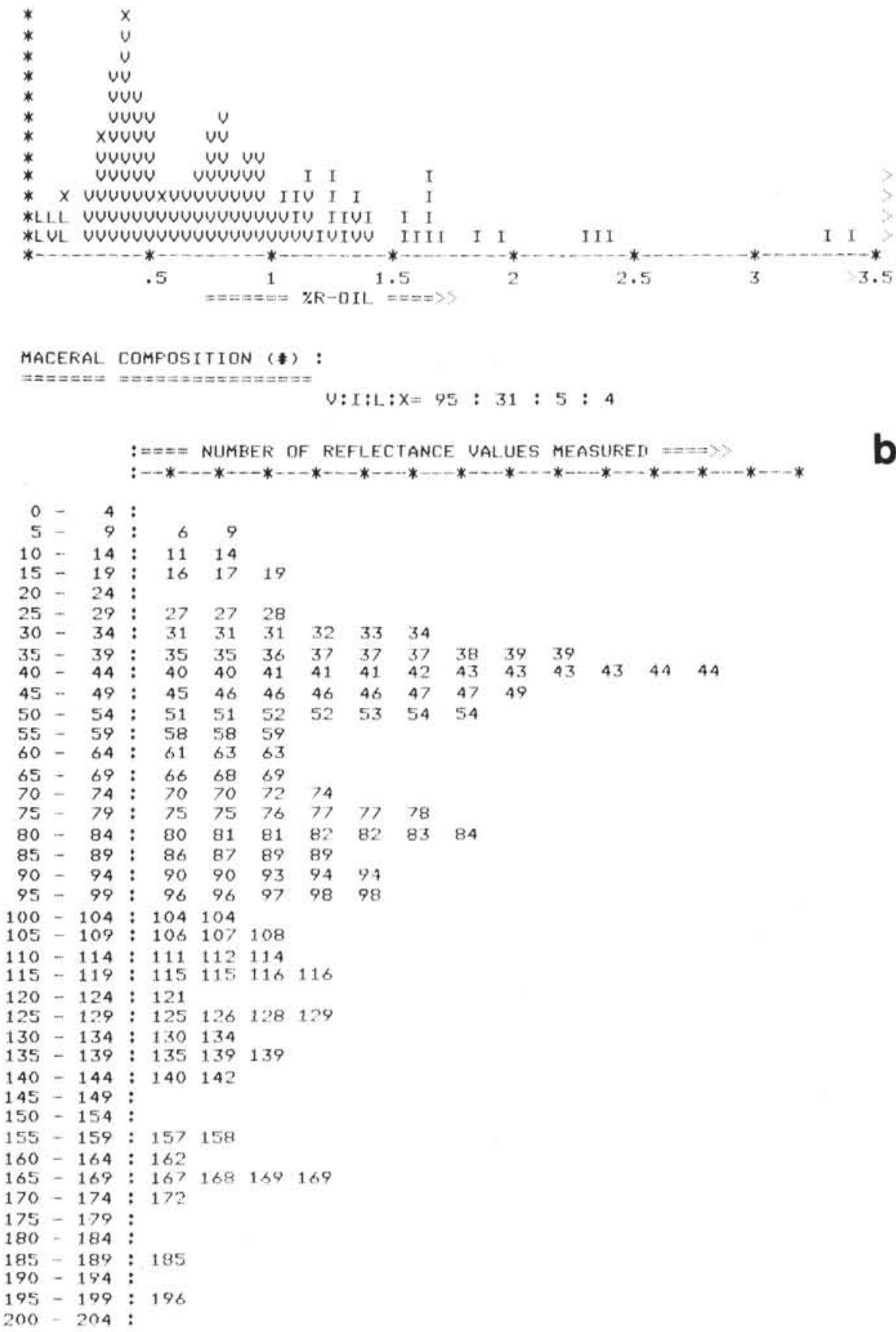

$\begin{array}{lll}0 & 4: & \\ 5-9 & 6 & 9\end{array}$

$10-14: 11 \quad 14$

$15-19: 16 \quad 17 \quad 19$

$20-24:$

$25-29: 27 \quad 27 \quad 28$

$30-34: 313131$

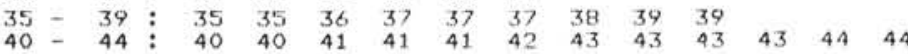

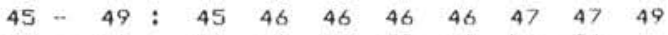

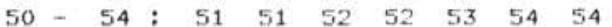

$55-59: 58 \quad 5859$

$60-64: 616363$

$65-69: 66 \quad 6869$

$70-74: 70707274$

$75-79: 75 \quad 75 \quad 76 \quad 77 \quad 77 \quad 78$

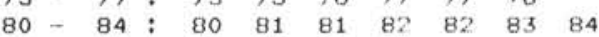

$85-89: 86878989$

$90-94: 9090939497$

$95-99: 96 \quad 96 \quad 97 \quad 98 \quad 98$

$100-104: 104104$

$105-109: 106107108$

$110-114: 111 \quad 112114$

$115-119: 115115116116$

$120-124: 121$

$125-129: 125126128 \quad 129$

$130-134: 130134$

$135-139: 135139139$

$140-144: 140142$

$145-149:$

$150-154:$

$155-159: 157158$

$160-164: 162$

$165-169: 167168169169$

$170-174: 172$

$175-179:$

$180-184:$

$185-189: 185$

$190-194:$

$195-199: 198$

$200-204:$

Figure 7. Reflectance histograms of kerogen particles from Section 434B-15-1. a. Macerals, using codes $V=$ huminite/vitrinite, $I=$ inertinite, $L=$ liptinite, and $X=$ unknown. b. Reflectance values $(\times 100)$ plotted at 0.05 per cent intervals; mean reflectance of lowest peak is 0.41 per cent.

Hagemann (Rheinisch-Westfälische Technische Hochschule, Aachen), and Dr. D. Leythaeuser (Kernforschungsanlage Jülich) for carefully reading and reviewing the manuscript.

Samples were made available by participation of the Deutsche Forschungsgemeinschaft (DFG) in the DSDP/LPOD program. This is gratefully acknowledged, as is financial support by the German Ministry for Research and Technology (BMFT), grant No. ET 3070 B.

\section{REFERENCES}

Cornford, C., 1979. Organic petrography of Lower Cretaceous shales at DSDP Leg 47B, Site 398, Vigo Seamount, eastern North Atlantic. In Ryan, W. B. F., Sibuet, J.-C., et al., Init. Repts. DSDP, 47, Part 2: Washington (U.S. Govt. Printing Office), 523-528.

Cornford, C., Rullkötter, J., and Welte, D. H., 1979. The organic geochemistry of DSDP Leg 47A, Site 397, eastern 
E.O.G. NUMEER: K4619C.MJA IAATE: 25-AUG-78
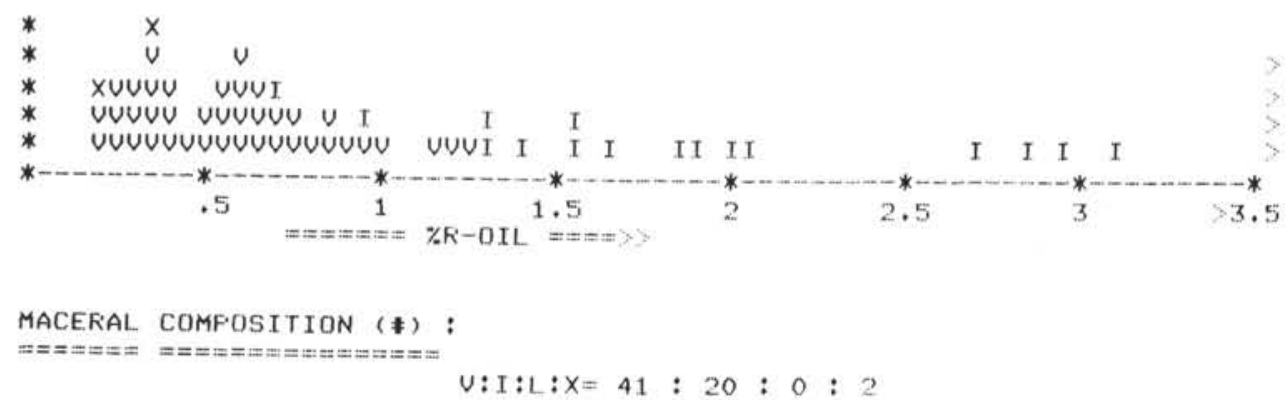

Figure 8. Maceral-reflectance histograms of kerogen particles. a. Section 436-7-4, mean reflectance of lowest peak is 0.32 per cent. b. Section 438-10-4.

North Atlantic: organic petrography and extractable hydrocarbons. In Ryan, W. B. F., von Rad, U., et al., Init. Repts. DSDP, 47, Part 1: Washington (U.S. Govt. Printing Office), 511-522.

Dow, W. G., 1978. Petroleum source beds on continental slopes and rises. Bull. Am. Assoc. Petrol. Geol., 62, 15841606.

Ishiwada, Y., and Ogawa, K., 1976. Petroleum geology of offshore waters around the Japanese Islands. United $\mathrm{Na}$ tions ESCAP, CCOP Tech. Bull., 10, 23-24.

Matveef, A. K., 1972. Map of the Coal Fields of the World. Moscow (Nedra).

Nishimura, M., 1978. Geochemical characteristics of the high reduction zone of stenols in Suwa sediments and the en- vironmental factors controlling the conversion of stenols to stanols. Geochim. Cosmochim. Acta, 42, 349-57.

Radke, M., Sittardt, H. G., and Welte, D. H., 1978. Removal of soluble organic matter from rock samples with a flowthrough extraction cell. Anal. Chem., 50, 663-5.

Scholl, D. W., and Marlow, M. S., 1974. Sedimentary sequence in modern Pacific trenches and the deformed circum-Pacific eugeosyncline. Soc. Econ. Paleont. Mineral., Spec. Publ., 19, 193-211.

Stach, E., Mackowski, M. Th., Teichmüller, M. Taylor, G. H., Chandra, D., and Teichmüller, R., 1975. Stach's Textbook of Coal Petrology (2nd Edition): Berlin (Gebrüder Borntraeger).

Welte, D. H., Cornford, C., and Rullkötter, J., 1979. Hydrocarbon source rocks in deep sea sediments. Proc. IIth Annual Offshore Tech. Conf., 1, 457-464. 


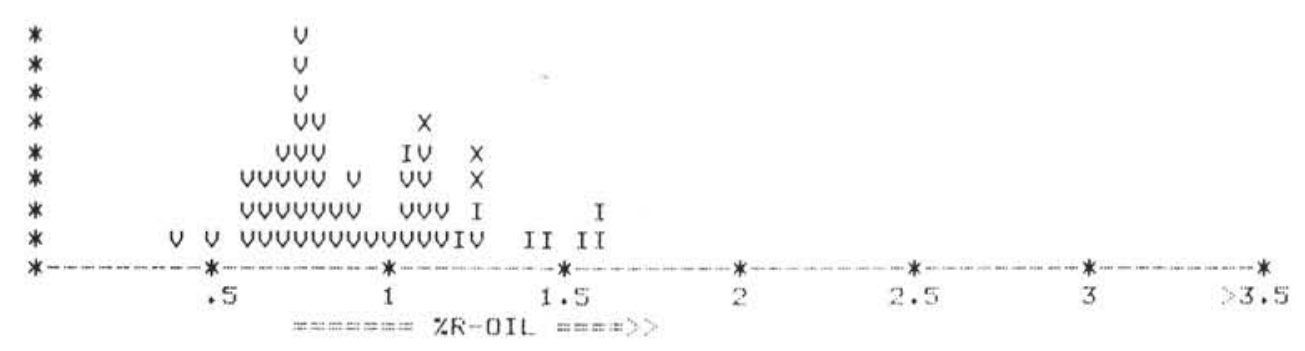

MACERAL COMFOSITION (*):

$======$ U: $\mathrm{I}: \mathrm{L}: \mathrm{X}=42: 8: 0: 3$

E.0.G. NUMBEK: K4641J.JOA TATE: 29-AUG-78

b

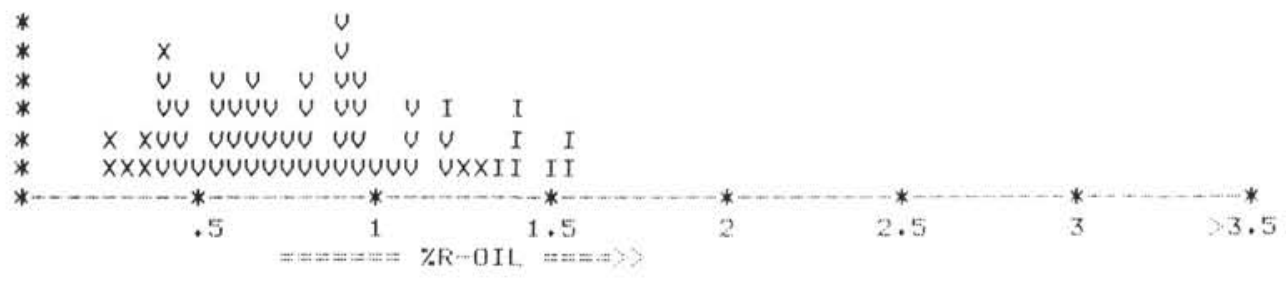

MACERAL COMPOSITION (†):

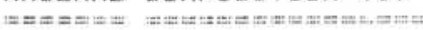

V:I:L:X: $=46: 8: 0: 8$

KEY:U UITKINITE, I=INERTINITE, L=LIFTINITE, $X=$ UNKNOWN. : VALUE $3.5 \%$

\#HASEI ON FOLISHEU FARTICLES, IE. NO AMORPHOUS MATTER.

Figure 9. Maceral-reflectance histograms of kerogen particles. a. Section 439-31-5, mean reflectance of lowest peak is 0.74 per cent. b. Section 440B-39-3, mean reflectance of lowest peak is 0.43 per cent. 


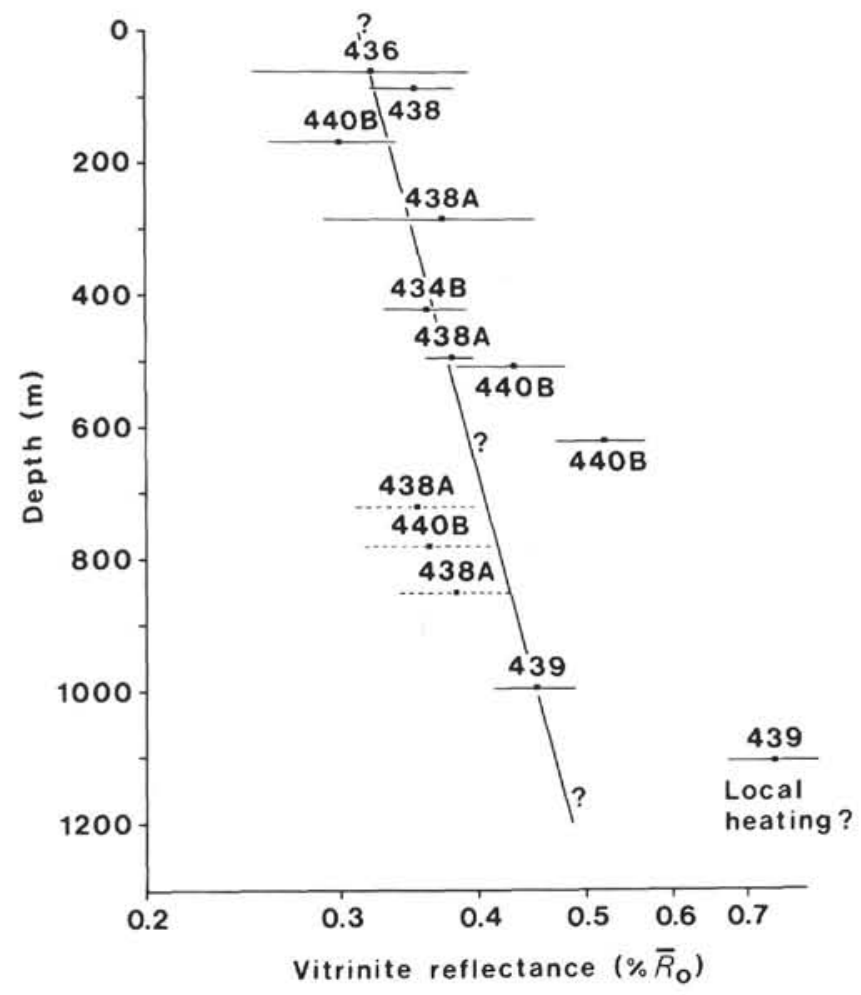

Figure 10. Mean huminite/vitrinite-reflectance values for samples from DSDP Legs 56 and 57, Japan Trench. The arithmetic mean and a standard deviation are plotted as a point and bar, respectively. The trend line may not be realistic, as argued in the text.

TABLE 5

Huminite/Vitrinite Reflectance Data

\begin{tabular}{|c|c|c|c|c|c|c|}
\hline \multirow{2}{*}{$\begin{array}{l}\text { Sample } \\
\text { (interval in } \mathrm{cm} \text { ) }\end{array}$} & \multirow{2}{*}{$\begin{array}{l}\text { Sub-Bottom } \\
\text { Depth } \\
\text { (m) }\end{array}$} & \multicolumn{4}{|c|}{$\begin{array}{l}\text { Lowest-Reflectance } \\
\text { Huminite/Vitriniteal }\end{array}$} & \multirow{2}{*}{$\begin{array}{l}\text { Comments on Total- } \\
\text { Reflectance Histogram }\end{array}$} \\
\hline & & $(\%)$ & $N$ & Std. Dev. & Range & \\
\hline $434 \mathrm{~B}-15-1,107-117$ & 419.1 & 0.36 & 8 & $(0.03)$ & $0.31-0.40$ & Multimodal (Figure 5). \\
\hline $436-7-4,115-125$ & 61.2 & 0.32 & 17 & $(0.07)$ & $0.20-0.43$ & Multimodal (1'igure 6). \\
\hline $\begin{array}{l}438-10-4,115-125 \\
438 A-24-4,110-120 \\
438 A-46-3,110-120 \\
438 A-70-4,110-120 \\
438 A-84-1,100-110\end{array}$ & $\begin{array}{r}84.7 \\
283.2 \\
492.7 \\
722.2 \\
850.5\end{array}$ & $\begin{array}{l}0.35 \\
0.37 \\
0.38 \\
0.35 \\
0.38\end{array}$ & $\begin{array}{r}16 \\
5 \\
13 \\
4 \\
3\end{array}$ & $\begin{array}{l}(0.03) \\
(0.08) \\
(0.02) \\
- \\
-\end{array}$ & $\begin{array}{l}0.30-0.40 \\
0.31-0.49 \\
0.35-0.42 \\
0.29-0.40 \\
0.37-0.39\end{array}$ & $\begin{array}{l}\text { Multimodal (Figure } 6 \text { ). } \\
\text { Broad peak between } 0.27 \text { and } 1.44 \% \text {. } \\
\text { Broad peak between } 0.17 \text { and } 1.02 \% \text {. } \\
\text { Not measured. } \\
\text { Scattered values between } 0.38 \text { and } 1.49 \% \text {. }\end{array}$ \\
\hline $\begin{array}{l}439-21-2,115-125 \\
439-31-5,0-5\end{array}$ & $\begin{aligned} & 994.7 \\
&-1105\end{aligned}$ & $\begin{array}{l}0.45 \\
0.74\end{array}$ & $\begin{array}{l}30 \\
23\end{array}$ & $\begin{array}{l}(0.04) \\
(0.07)\end{array}$ & $\begin{array}{l}0.37-0.54 \\
0.60-0.84\end{array}$ & $\begin{array}{l}\text { Not measured. } \\
\text { See Figure } 7 .\end{array}$ \\
\hline $\begin{array}{l}440 B-3-5,110-120 \\
440 B-39-3,115-125 \\
440 B-51-3,125-135 \\
440 B-68-2,110-120\end{array}$ & $\begin{array}{l}165.6 \\
504.7 \\
618.7 \\
778.6\end{array}$ & $\begin{array}{l}0.30 \\
0.43 \\
0.52 \\
0.36\end{array}$ & $\begin{array}{r}8 \\
12 \\
16 \\
3\end{array}$ & $\begin{array}{l}(0.04) \\
(0.05) \\
(0.05)\end{array}$ & $\begin{array}{l}0.23-0.34 \\
0.34-0.56 \\
0.42-0.58\end{array}$ & $\begin{array}{l}\text { Values between } 0.29 \text { and } 1.48 \% \text {. } \\
\text { See Figure } 7 \text {. } \\
\text { Multimodal between } 0.25 \text { and } 1.38 \% \text {. } \\
\text { Not measured. }\end{array}$ \\
\hline
\end{tabular}

$\Delta \bar{R}_{\mathrm{O}}$ is the arithmetic mean of selected huminite/vitrinite reflectance values; $N$ is the number of measurements. 

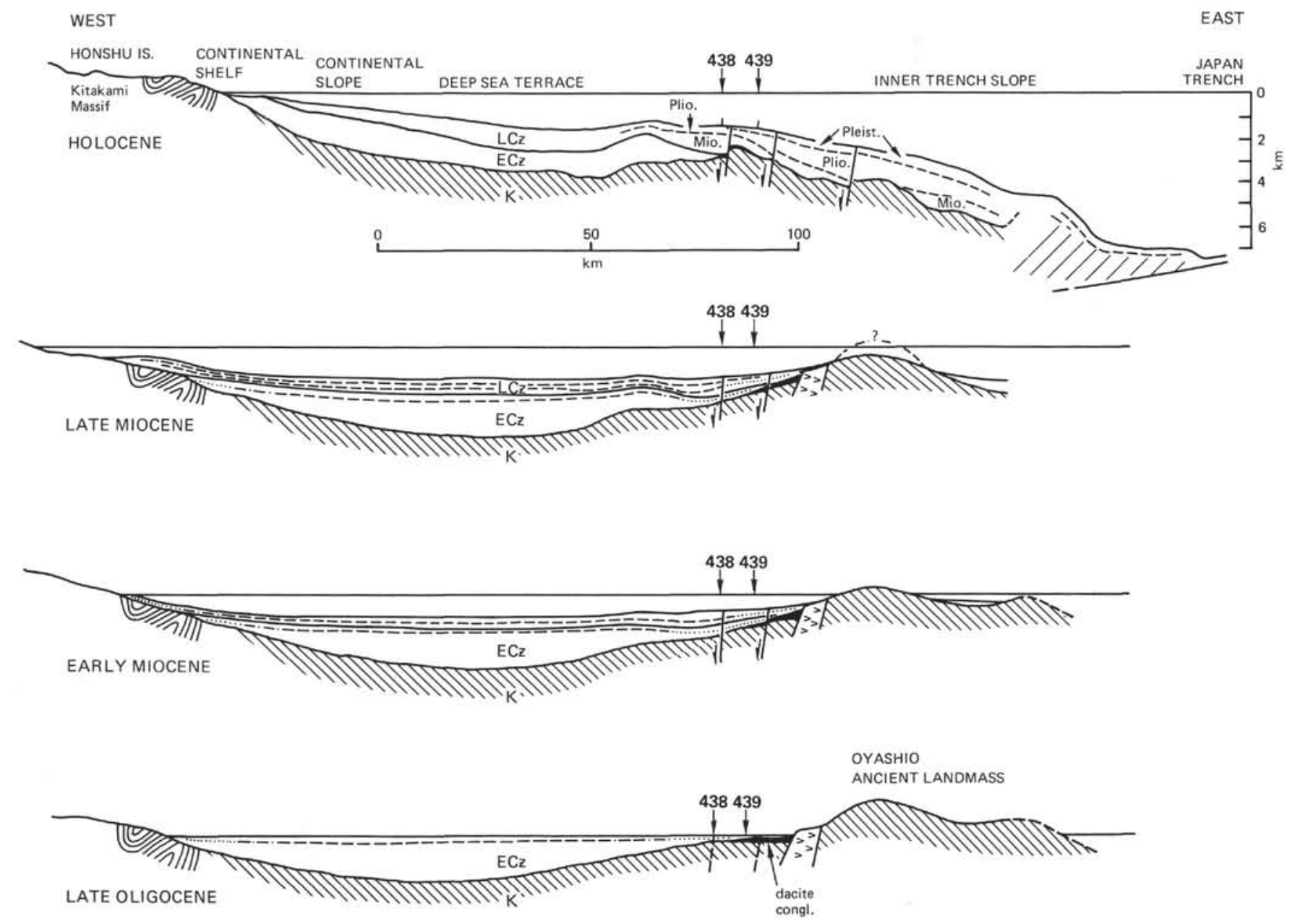

Figure 11. Diagrammatic history of subsidence of the Oyashio landmass, based on DSDP Leg 57 sampling and JNOC multichannel records. $K=$ Cretaceous, $E C z=$ early Cenozoic (Paleogene), $L C z=$ late Cenozoic (Neogene). Zone of accretion and oceanic igneous crust shown diagrammatically in the Holocene section. (Figure taken from Leg 57 shipboard summary.) 